\title{
Assessment of the geological heritage of Cape Mondego Natural Monument (Central Portugal)
}

\author{
João Rocha ${ }^{\mathrm{a}, *}$, José Brilha ${ }^{\mathrm{b}, \mathrm{c}}$, Maria Helena Henriques ${ }^{\mathrm{d}}$ \\ ${ }^{a}$ Geosciences Centre, University of Coimbra, Largo Marquês de Pombal, 3000-272 Coimbra, Portugal \\ ${ }^{\mathrm{b}}$ Geology Centre of the University of Porto, Rua do Campo Alegre, 687, 4169-007 Porto, Portugal \\ c Department of Earth Sciences of the University of Minho, Campus de Gualtar, 4710-057, Braga, Portugal

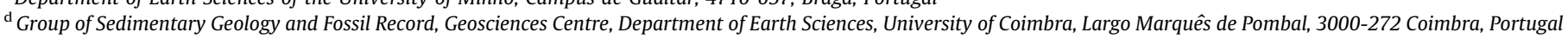

\section{A R T I C L E I N F O}

\section{Article history:}

Received 11 October 2012

Received in revised form 14 April 2013

Accepted 22 April 2013

Available online 28 May 2013

\section{Keywords:}

Cape Mondego

Geosites assessment

Geosite management

Natural Monument

\begin{abstract}
A B S T R A C T
In the western coast of Portugal, Cape Mondego is a well-known set of outcrops due to its international stratigraphic relevance given by the establishment of two stratotypes: the Global Boundary Stratotype Section and Point (GSSP) for the base of the Bajocian Stage and the Auxiliary Stratotype Section and Point (ASSP) for the base of the Bathonian Stage.

The remarkable geodiversity of these Jurassic outcrops justifies the implementation of strategies in order to conserve and promote the geosites, which include a rich palaeontological record of macrofossils, microfossils and dinosaur footprints.

Based on the exceptional quality of the geological record, on its international importance and on its high scientific and educational values, this area was classified in 2007 as Natural Monument. However, no geosite systematic inventory was ever done.

In this work, a systematic identification, characterization and assessment of geosites was done in the Natural Monument. Based on fieldwork and published data, a first set of 32 potential geosites was identified taking into account their scientific, educational and touristic values. After the application of three criteria (representativeness, singularity and proximity) this group of 32 potential geosites was reduced to 12 . These 12 geosites were assessed resulting on the establishment of a medium to high ranks for both educational and geotouristic potential uses. Based on this assessment, some valuing strategies were proposed, aiming at the sustainable use and the promotion of the Natural Monument geosites, within the scope of both educational and geotouristic activities addressed to secondary school students and the general public.
\end{abstract}

(c) 2013 Published by Elsevier Ltd on behalf of The Geologists' Association.

\section{Introduction}

The Cape Mondego outcrops (western part of Boa Viagem Mountain, Portugal) embody a remarkable scientific importance. These Jurassic outcrops must be the object of geoconservation strategies regarding their conservation and management. Aiming the protection and safe guard of both the Bajocian GSSP and the surrounding outcrops with their fossil record and also the development of scientific research and educational activities, this area was classified as Natural Monument in 2007 and integrated into the Portuguese Network of Protected Areas. The Portuguese protected areas panorama settles the geological objects protection mainly onto the Natural Monument (7 in Portuguese mainland)

\footnotetext{
* Corresponding author. Tel.: +351964223406.

E-mail addresses: joaorocha@uc.pt (J. Rocha), jbrilha@dct.uminho.pt (J. Brilha), hhenriq@dct.uc.pt (M.H. Henriques).
}

category, although there are other categories where those objects can be incorporated (Rocha, 2010). The majority of the Portuguese protected areas are focused on biological objects rather than geological, resulting on a higher number of protected areas based on bio aspects even though this trend has been facing some changes in recent years (Henriques, 2004). Regardless the vast scientific knowledge concerning the Jurassic relevance of Cape Mondego and the fact that it has been included in the inventory of the Portuguese geological heritage within the framework "Jurassic record in the Lusitanian Basin" (Brilha et al., 2005) and also the protection as Natural Monument, no systematic geosites inventory was ever carried out in this protected area.

Geoconservation encloses a set of strategies to support the geoheritage conservation, regarding the analysis of its values, as well as the evaluation of its vulnerability. A geoconservation strategy must combine a series of integrated phases, from which the combined result leads to the establishment of conservation, interpretation and management actions. The lack of the inventory 
stage is an inappropriate geoconservation project beginning and it may lead to an inadequate protection of the significant geological objects resulting, therefore, on the loss of integrity or even destruction. Lima et al. (2010) reiterated this idea pointing out some examples from five Portuguese Natural Monuments.

During the last years, several studies have been conducted regarding the assessment and management of geosites and also the definition of geoconservation strategies (e.g. Serrano and González-Trueba, 2005; Pereira et al., 2007; Reynard, 2009; Lima et al., 2010; Kavčič and Peljhan, 2010; Coratza et al., 2011; Fassoulas et al., 2011; Pellitero et al., 2011). There is also a great number of assessment methods to rank the different values of geosites from a particular territory (Grandgirard and Szepesi, 1997; Panizza and Piacente, 2003; Gray, 2004; Brilha, 2005; Reynard, 2005; Reis and Henriques, 2009).

The present work is focused on the identification, characterization and assessment of the geosites in Cape Mondego Natural Monument in order to contribute for the development of a future management plan, once no geoconservation strategy was ever made and no management plan was ever established by the national authority for this protected area. This work also aims to establish geoconservation proposals for the Natural Monument, as well as to suggest interpretation resources addressed to both educational and geotourism uses.

\section{The study area}

The Cape Mondego is located on the Atlantic coast of Central Portugal on the western border of Boa Viagem Mountain, $6 \mathrm{~km}$ northwest from Figueira da Foz and approximately half distance between Oporto and Lisbon (see Fig. 1). The Cape Mondego Natural Monument occupies an area of about $1.2 \mathrm{~km}^{2}$ (58\% onshore and $42 \%$ offshore).

The Cape Mondego is known worldwide due to the scientific importance of the Jurassic record and to the establishment of both the Global Boundary Stratotype Section and Point for the Bajocian Stage (Bajocian GSSP; Pavia and Enay, 1997) and the Auxiliary Stratotype Section and Point for the Bathonian Stage - Bathonian ASSP (Fernández-López et al., 2009).

The initial steps to promote the classification of Cape Mondego as a Natural Monument started in 1994. But it was only after more than a decade that the administrative process that lead to the creation of this Natural Monument was concluded with the publication of the Decree No. 82/2007 (Henriques, 2004, 2008). Some of the key-outcrops of Cape Mondego were then integrated into the Portuguese Network of Protected Areas. This legal status aimed the protection and safe guard of the Aalenian-Bajocian Stratotype, as well as the surrounding outcrops and their fossil record. The development of scientific research and educational activities are also mentioned as a primary aim in the legal document, which stresses the international importance of the geological record and its stratigraphic relevance.

\section{Geological setting}

The Cape Mondego section records a marine series of marly and limestone sediments representing the later Toarcian to middle Callovian times -185 to $140 \mathrm{Ma}$ (Mouterde et al., 1978; Rocha et al., 1981; Henriques, 1998a,b), where particularly significant sedimentary, stratigraphic and palaeomagnetic data have been described (Henriques et al., 1988; Henriques, 2004), as well as relevant palaeontological data has been recognized: ammonites, brachiopods, benthic foraminifera, calcareous nanofossils, radiolaria and ichnofossils (Henriques, 2008). The highly significant biostratigraphic and biochronological values displayed by the

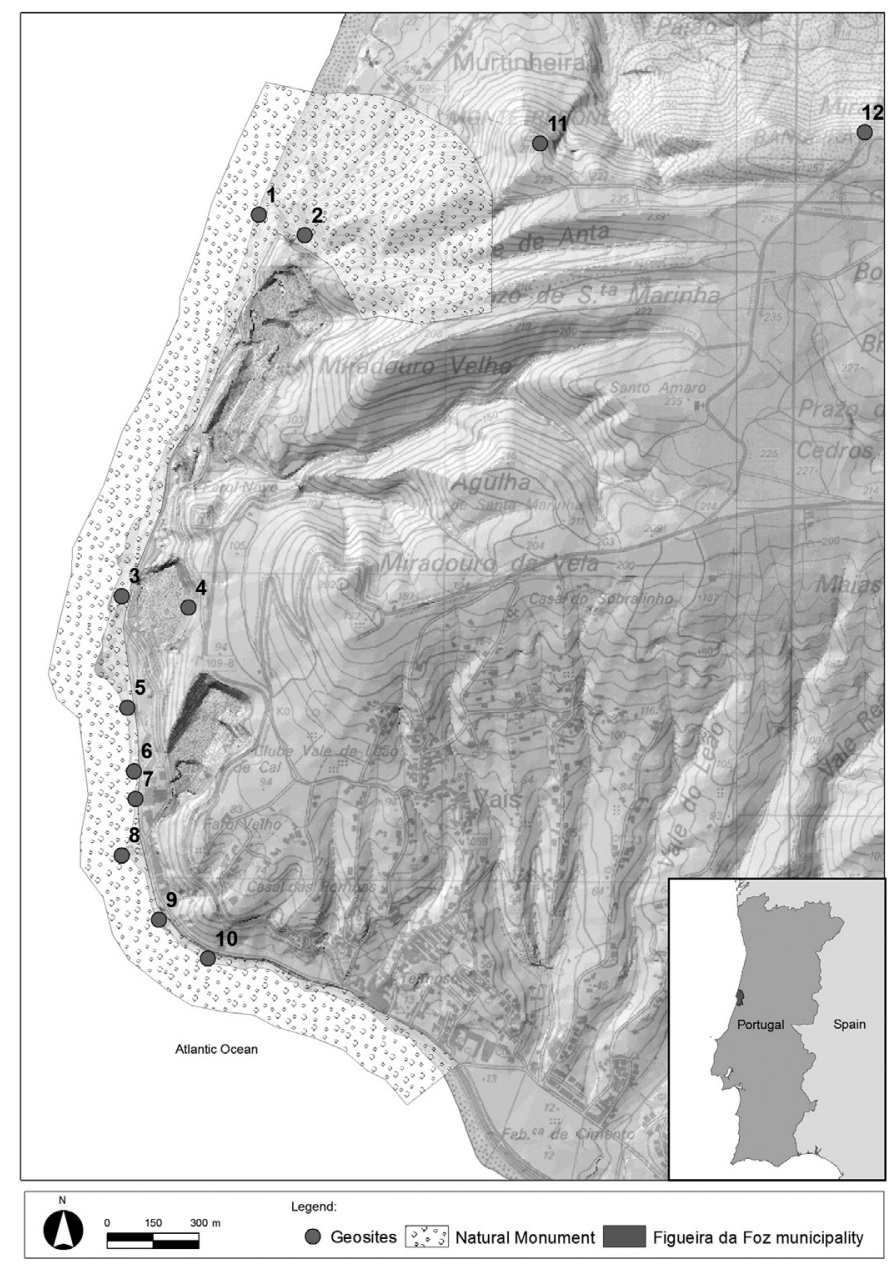

Fig. 1. Cape Mondego Natural Monument boundaries and geosites location represented on the topographical map of Figueira da Foz municipality. Geosites No. 1 - GSSP (Bajocian); No. 2 - Anta valley; No. 3 - ASSP (Bathonian); No. 4 - MiddleUpper Jurassic Discontinuity; No. 5 - Callovian stratigraphic and palaeontological record; No. 6 - Syn-rift deposits; No. 7 - Dinosaur footprint and ripples marks; No. 8 - Dinosaur footprints and mud cracks; No. 9 - Syn-rift deposits (climax); No. 10 Fluvial-deltaic deposits; No. 11 - Monte Redondo panoramic view; No. 12 Bandeira viewpoint.

ammonite record allowed the recognition of several biostratigraphic units, across the entire Middle Jurassic sediments.

The upper Jurassic sediments from Cape Mondego section represents the Lusitanian Basin second rifting episode (Reis, 2008), displaying diversified marginal depositional facies (lagoon, delta, estuarine), with abundant record of corals, echinoderms, brachiopods, crinoids and dinosaurs footprints. The rifting episode has lead to a widespread carbon deposition, which was an important mining resource during the 19 th and 20th centuries.

From the scientific point of view, the geological importance of Cape Mondego outcrops is known since 1884 due to a research study focused on the presence of dinosaur footprints, which in reality was the first one carried out in Portugal and also one of the first to ever been published in Europe (Henriques, 1998a; Lockley et al., 1998; Holtz, 1998). During the 19th and 20th centuries several scientists discussed the ammonite record and its stratigraphic value, as well as the occurrence of other fossil groups: benthic foraminifera, calcareous nannoplankton and brachiopods (Rocha, 2010).

The occurrence of a particularly rich and diversified ammonite fossil record, the occurrence of calcareous nannofossils, the continuity of the stratigraphic record and the magnetostratigraphic polarity-reversal across the Aalenian-Bajocian boundary 
supported the proposal of the establishment of the Bajocian Global Stratotype Section and Point (GSSP) at Cape Mondego outcrops, more exactly in Murtinheira section (Rocha et al., 1990; Henriques et al., 1994; Fig. 2).

The formal establishment of the Aalenian-Bajocian boundary (Bajocian GSSP), the first stage boundary established for the Jurassic System and the only one existing so far in Portugal, occurred in 1996 (Pavia and Enay, 1997). The GSSP was defined in the base of bed AB11, according to the biostratigraphic relevance of the Ammonoidea record, particularly due to the first occurrence of Hyperlioceras associations - $H$. mundum and related species $(H$. furcatum, Braunsina aspera, B. elegantula) and also to the late occurrence of Graphoceras and Haplopleuroceras (Henriques et al., 1994).

More recently, other fossil groups have been studied in detail across the GSSP (calcareous nannoplakton, benthic foraminifers and brachiopods), and the obtained results emphasize the relevance of the Aalenian-Bajocian boundary at Cape Mondego for global correlation (Canales and Henriques, 2008, 2013; Neto et al., 2011).

The international scientific significance of the Middle Jurassic of Cape Mondego section assumed a higher rank value with the establishment of the ASSP for the Bajocian-Bathonian boundary. The ASSP for the base of the Bathonian Stage established in 2008 provided complementary data (ammonite succession and biochronostratigraphic subdivision) to the Bathonian GSSP, which was defined at the base of limestone bed RB071 in the Ravin du Bès Section, Bas-Auran, in southern Subalpine Chains (France) (Fernández-López et al., 2009).

\section{Geosites inventory}

In spite of the vast scientific documentation concerning the Jurassic relevance of Cape Mondego, no systematic inventory of geosites was ever made in the whole area of the Natural Monument.

After an initial identification of potential geosites using the methodology proposed by Brilha (2005) and adapted to the local specificities, 32 potential sites were defined. In order to select the most representative geosites of the Natural Monument, three criteria were applied to these 32 potential geosites: representativeness, singularity and proximity. The representativeness criterion is related with the appropriateness of the geosite to illustrate a geological process or feature, which brings a meaningful contribution to the understanding of the geological topic, process or feature. The singularity criterion regards the number of similar occurrences of a geological process or feature on a specific area. The proximity criterion considers the possibility of having different relevant geological processes or features that might be integrated in the same geosite. After applying these three criteria, the initial list of 32 potential sites was reduced to 12 geosites (Fig. 1). Two of these geosites are located outside the boundaries of the Natural Monument but they were selected because they are the best sites to have a general view over the entire area.

Aiming the potential use for educational and tourism purposes and also following the proposed evaluation system from Reis and Henriques (2009) for values or contents displayed by geological objects, the 12 geosites were classified according to the different types of contents. The proposed open system intents to qualify geological objects with heritage value according to its content, based on the relevance defined by scientific communities as well as the public understanding of geological objects, which is related with its social fruition. The quantification of the contents settles a base for grouping geological objects and they can be assumed as: Indicial (geological objects as indexes - relevant to illustrated detailed geological features); Iconographic (e.g. Bandeira viewpoint); Symbolic (place used by the public due to other reasons different from the geological ones); Documental (a highly demonstrative record which is relevant for the understanding of significant geologic features on a regional scale - e.g. Cape Mondego outcrops); Scenic (high recreational function of a geological object/phenomena on a regional scale - e.g. Monte Redondo); Conceptual (singular geological occurrences that can be used as excellent examples of material and theoretical references for geology - e.g. GSSP and ASSP).

The scientific relevance of this Natural Monument was well demonstrated in the geological setting section. So, the scientific use for the 12 geosites is assumed without further considerations. However, for management purposes the potential educational and tourism uses of these geosites need to be assessed. Five geosites (No. 1, 7, 8, 9, and 10) are located near the seashore that might imply temporary use restrictions (Fig. 1).

\subsection{Assessment of the potential educational use}

The Cape Mondego Natural Monument is mentioned in the national curriculum for several disciplines of the secondary
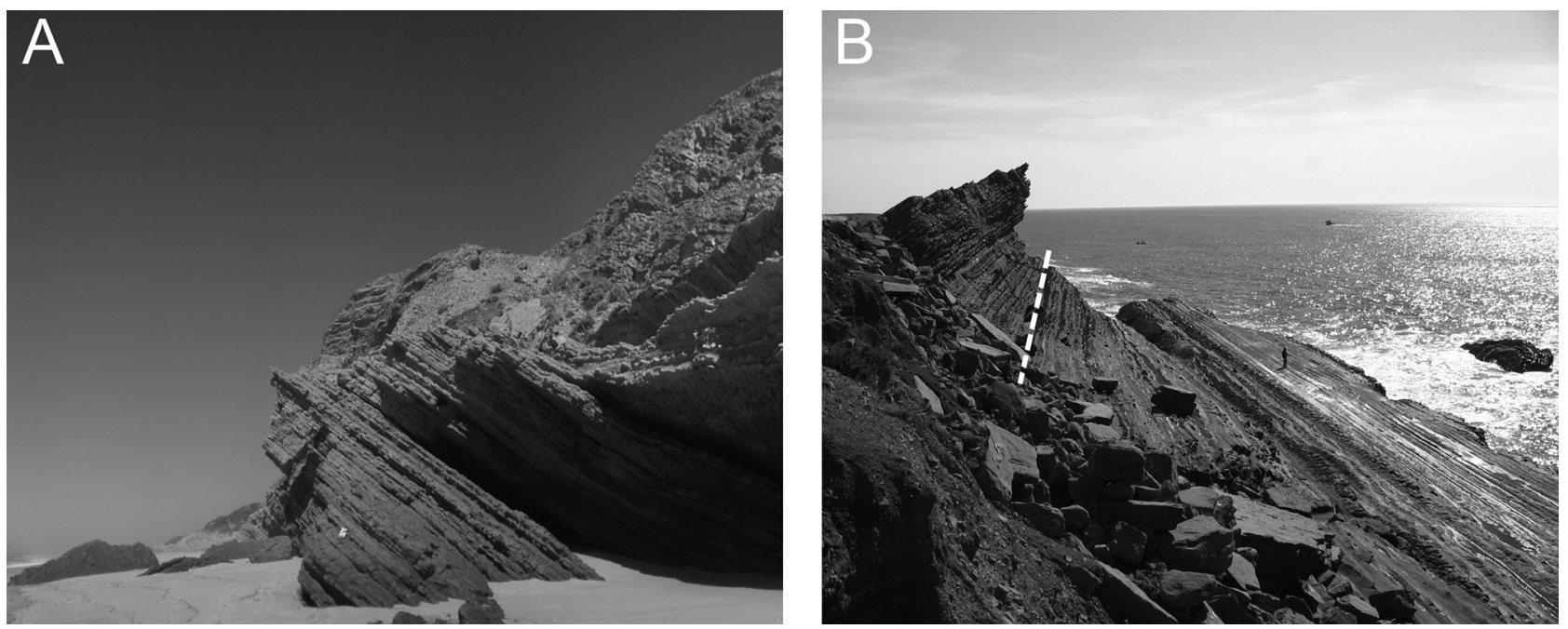

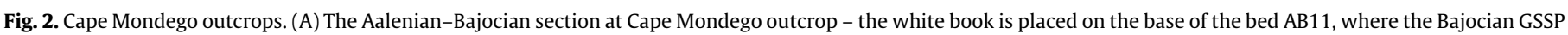
has been defined. (B) The Bajocian-Bathonian section - the dotted line shows the lower boundary on which the Bathonian ASSP was established. 
education (Biology and Geology - 10th, 11th and 12th grades; Geology - 12th grade). This is clearly an evidence of the high educational relevance of this protected area for Geology education, when used as an educational resource accordingly articulated with activities integrated in the curriculum (Henriques et al., 2012). To assess the potential for educational use of the 12 geosites, the following criteria were evaluated (Table 1 ): accessibility, associated resources, viewing conditions, educational content, fragility and representativeness. These criteria were evaluated with a scale of one to five points, according to Braga (2002).

Accessibility is an important factor when considering the educational potential use of a geosite. Students need to reach a geosite safely, not spending too much time and usually in groups of about 40 elements. This criterion was evaluated considering that the best possibility ( 5 points) happens when a school bus easily reaches the geosite.

The association between geological contents and cultural components (existence of quarry buildings and the related mining history) was considered a good motivation to develop interdisciplinary educational activities. The distance between geological and cultural assets was used to rank this criterion.

The criterion viewing conditions expresses the quality of the geosite visualization. The higher rank means exceptional viewing conditions in the full extent of the geosite, together with the opportunity to observe all geological features or processes.

The educational criterion assesses the capability of a geosite to clearly exemplify educational contents to students and general public. The higher score is used for geosites with clear and easy geological contents allowing its educational use for all levels of teaching and also for the general public.

Table 1

Criteria to assess the potential educational use of geosites.

Points

Accessibility (Ac) criterion

Direct access by municipal/national road

Less than a $1 \mathrm{~km}$ from any pathway for passenger vehicles (cat. D)

More than a $1 \mathrm{~km}$ from any pathway for passenger vehicles (cat. D)

Less than a $1 \mathrm{~km}$ from any pathway for vehicles (cat. D1, B)

Direct access on a non-paved road (cat. B)

Association with other resources (Ar) criterion

Association with other features up to $500 \mathrm{~m}$ distance

Association with other features up to $1000 \mathrm{~m}$ distance

No associated features

Viewing conditions (Vie) criterion

Exceptional viewing conditions (to the fullest extent and easily-observable)

Good viewing conditions (to the fullest extent but with some difficulty)

Median viewing conditions (not observable in the fullest extent)

Educational content (Edu) criterion

Clearly exemplifies educational contents to any teaching level and to the general public

Clearly exemplifies educational contents to any teaching grade

Clearly exemplifies educational contents for graduate

and post-graduate studies

Fragility (Fra) criterion

Decametric dimension sites hardly affected by anthropogenic activities

Decametric to metric dimension sites moderately affected by anthropogenic activities

Metric dimension sites easily affected by any

anthropogenic activity

Representativeness (Rpr) criterion

Best example in Portugal of a geological process or feature

Best example in Cape Mondego of a geological process or feature

Representative of various geological contexts
The geosite fragility is closely linked to the negative impacts of anthropogenic activities that can lead to a series of events from minor damage or loss to partial or total destruction. The fragility was defined on a decametric to metric extent bases, in which geosites with decametric dimension that could hardly be affected by anthropogenic activities have a higher score, e.g. the GSSP and the ASSP geosites.

The calculation of the potential educational use (PEU) is based on the relative weights proposed by Braga (2002) and followed by Rocha (2010).

$$
\mathrm{PEU}=\frac{\begin{array}{c}
{[(\text { Ac } \times 20)+(\text { Ar } \times 10)+(\text { Vie } \times 15)+(E d u \times 20)} \\
+(\text { Fra } \times 15)+(R p r \times 20)]
\end{array}}{6}
$$

The results were reclassified in order to get a qualitative perspective concerning the PEU for the 12 geosites (Table 2): low $(<30)$, medium (30-60) and high $(>60)$.

The majority of the Cape Mondego geosites present a high potential to be used for educational activities. Only 2 of them (Callovian stratigraphic and palaeontological record; Fluvialdeltaic deposits) have a medium PEU (Table 2).

\subsection{Assessment of the potential geotourism use}

The geotourism potential of a geosite is commonly related to the presence of spectacular scenic aspects, once the landscapes are at the top of the hierarchy pyramid of features of geotourism interest (Newsome and Dowling, 2006). If the scientific importance is considered, a new perception can be added to the geological tourism resulting in a scientific geotourism - e.g. the GSSP and the ASSP do not have magnificent scenic value, even though they are important geological features that can support geotourism activities (Rocha, 2010).

Following Braga (2002), the assessment of the potential geotourism use (PGU) is based on 5 criteria (Table 3 ), four of them similar to the ones used for PEU evaluation.

The accessibility now considers that the target public will be travelling with their personal vehicles instead of the large capability vehicles (e.g. school buses) previously considered on the PEU assessment.

The spectacularly criterion tries to deal with an irrefutable subjectivity but with significant importance to evaluate tourism potential. Spectacularly assessment is based on the actual use of a geosite as an icon in tourism marketing strategies, campaigns and documents (Braga, 2002). To get a precise quantification of Cape Mondego usage as icon a wide group of supports that are published by tourism agencies were evaluated (Turismo Centro Portugal,

Table 2

Results of the potential educational use (PEU) of the inventoried geosites.

\begin{tabular}{lll}
\hline Geosite name and number & $\begin{array}{l}\text { Potential } \\
\text { educational } \\
\text { use (PEU) }\end{array}$ & $\begin{array}{l}\text { Geosite PEU } \\
\text { average } \\
\text { weight }\end{array}$ \\
\hline GSSP (Bajocian) - No. 1 & High & 65 \\
Anta valley - No. 2 & High & 68 \\
ASSP (Bathonian) - No. 3 & High & 65 \\
Middle-Upper Jurassic Discontinuity - No. 4 & High & 63 \\
Callovian stratigraphic and & Medium & 57 \\
$\quad$ palaeontological record - No. 5 & High & 63 \\
Syn-rift deposits - No. 6 & High & 67 \\
Dinosaur footprint and ripple marks - No. 7 & High & 67 \\
Dinosaur footprints and mud cracks - No. 8 & High & 65 \\
Syn-rift deposits (climax) - No. 9 & Medium & 59 \\
Fluvial-deltaic deposits - No. 10 & High & 63 \\
Monte Redondo panoramic view - No. 11 & High & 68 \\
Bandeira viewpoint - No. 12 & &
\end{tabular}


Table 3

Criteria and respective weight use for geotourism use assessment.

\begin{tabular}{|c|c|}
\hline & Points \\
\hline \multicolumn{2}{|l|}{ Accessibility $(A c)$ criterion } \\
\hline Direct access by municipal/national road & 5 \\
\hline Direct access by a pathway or a paved road & 4 \\
\hline Direct access by a pathway or a non-paved road & 3 \\
\hline Less then a $1 \mathrm{~km}$ distance from any pathway & 2 \\
\hline More then a $1 \mathrm{~km}$ distance from any pathway & 1 \\
\hline \multicolumn{2}{|l|}{ Association with other resources $(A r)$ criterion } \\
\hline Association with other features up to $500 \mathrm{~m}$ distance & 5 \\
\hline Association with other features up to $1000 \mathrm{~m}$ distance & 3 \\
\hline No associated features & 1 \\
\hline \multicolumn{2}{|l|}{ Educational content (Edu) criterion } \\
\hline $\begin{array}{l}\text { Clearly exemplifies educational contents to any teaching } \\
\text { level and to the general public }\end{array}$ & 5 \\
\hline Clearly exemplifies educational contents to any teaching grade & 4 \\
\hline $\begin{array}{l}\text { Clearly exemplifies educational contents for graduate } \\
\text { and post-graduate studies }\end{array}$ & 3 \\
\hline \multicolumn{2}{|l|}{ Spectacularly (Spe) criterion } \\
\hline Used for national tourism iconography & 5 \\
\hline Used for local tourism iconography & 3 \\
\hline Not used for tourism iconography & 1 \\
\hline \multicolumn{2}{|l|}{ Fragility (Fra) criterion } \\
\hline $\begin{array}{l}\text { Decametric dimension sites hardly affected by } \\
\text { anthropogenic activities }\end{array}$ & 5 \\
\hline $\begin{array}{l}\text { Decametric to metric dimension sites moderately } \\
\text { affected by anthropogenic activities }\end{array}$ & 3 \\
\hline $\begin{array}{l}\text { Metric dimension sites easily affected by any } \\
\text { anthropogenic activity }\end{array}$ & 1 \\
\hline
\end{tabular}

Turismo de Portugal, Figueira Grande Turismo, and Figueira Digital). The sites that are national tourism symbols received a higher score.

The PGU calculation was based on the following formula:

$\mathrm{PGU}=\frac{[(A c \times 25)+(A r \times 20)+(E d u \times 5)+(S p e \times 30)+(\text { Fra } \times 20)]}{5}$

The spectacularly criterion has the highest relative weight because it plays a decisive role in the promotion of geotourism activities. On the other hand, the educational content has the lowest weight as proposed by Rocha (2010). The resulting formula values were reclassified in order to obtain the rank on the PGU scales (Table 4$)$, which vary from low $(<30)$ to medium $(30-60)$ and high $(>60)$.

The 12 geosites of Cape Mondego are equally distributed between medium and high potential for tourism use.

Table 4

Results of the potential geotourism use (PGU) of the inventoried geosites.

\begin{tabular}{lll}
\hline Geosite name and number & $\begin{array}{l}\text { Potential } \\
\text { geotourism } \\
\text { use (PGU) }\end{array}$ & $\begin{array}{l}\text { Geosite PGU } \\
\text { average } \\
\text { weight }\end{array}$ \\
\hline GSSP (Bajocian) - No. 1 & $\begin{array}{l}\text { Medium } \\
\text { Anta valley - No. 2 }\end{array}$ & 61 \\
ASSP (Bathonian) - No. 3 & Medium & 44 \\
Middle-Upper Jurassic Discontinuity - No. 4 & Medium & 44 \\
Callovian stratigraphic and palaeontological & Medium & 42 \\
record - No. 5 & Medium & 54 \\
Syn-rift deposits - No. 6 & High & 69 \\
Dinosaur footprint and ripple marks - No. 7 & High & 69 \\
Dinosaur footprints and mud cracks - No. 8 & High & 51 \\
Syn-rift deposits (climax) - No. 9 & Medium & 37 \\
Fluvial-deltaic deposits - No. 10 & Medium & 45 \\
Monte Redondo panoramic view - No. 11 & High & 84 \\
Bandeira viewpoint - No. 12 & & \\
\hline
\end{tabular}

\section{Valuing strategies}

According to Brilha (2002) protected areas have potential importance for environmental education and they can also be used for increasing the public awareness for nature conservation. Gray (2008) takes in consideration the idea that geodiversity can be a used as a basis for the development of geotourism activities. In order to promote the use of the Cape Mondego geosites and geodiversity, several resources were developed addressed to general public and secondary school students.

\subsection{The Geosites Map}

The Geosites Map presents informative support about the geosites geographical location as well as a brief text description of the contents of each geosite. The 2 geosites related with scenic aspects but located outside the formal limits of the natural monument (Bandeira viewpoint and Monte Redondo panoramic view) were not included in this map.

\subsection{Textbook}

A simplified textbook was also produced in order to support educational activities developed by secondary school teachers (Fig. 3). Priority was given to the use of images, in favour of a better understanding of the significant features of each geosite.

\subsection{Informative panel}

Finally, an informative panel was created based on simple and understandable text, with some panoramic and detail images and a geosites location map (Fig. 4). This panel should be placed in the south entrance of the Natural Monument, a location highly visited by the public with good car parking facilities.

\section{Conclusions}

As it is argued in the Declaration of the Rights of the Memory of the Earth - Digne, human activities should preserve Nature in all its facets, in particular with respect to the Earth's geological heritage, its conservation and protection. The link between anthropogenic activity and sustainable use of geological values should be enhanced by the development of planning policies pointed to the geoconservation (Henriques et al., 2011). The existence of several threats to geodiversity integrity (Gray, 2011) requires the development of major geoconservation plans and valuing strategies, as geodiversity can provide a wide range of geosystem services with several associated goods and functions witch are extremely important for human activities. The geosystem services values loss will increase, as geoconservation is not taken in account in sustainable management polices.

The Cape Mondego Natural Monument represents one of the fewest Portuguese protected areas created solely on geological values in order to guarantee the preservation of its exceptional geological heritage. The legal classification document highlights the exceptional quality of the geological record and stresses its unbeatable educational and scientific values.

The present work had intended to contribute to the conservation of Cape Mondego geosites and it is focussed on the following objectives: identification and characterization of geosites according to their potential use and the development of informative resources. The geosites identification and characterization took into account the potential educational and tourism uses and therefore the considered criteria and weights allowed the establishment of geosites ranking according to their potential uses. 


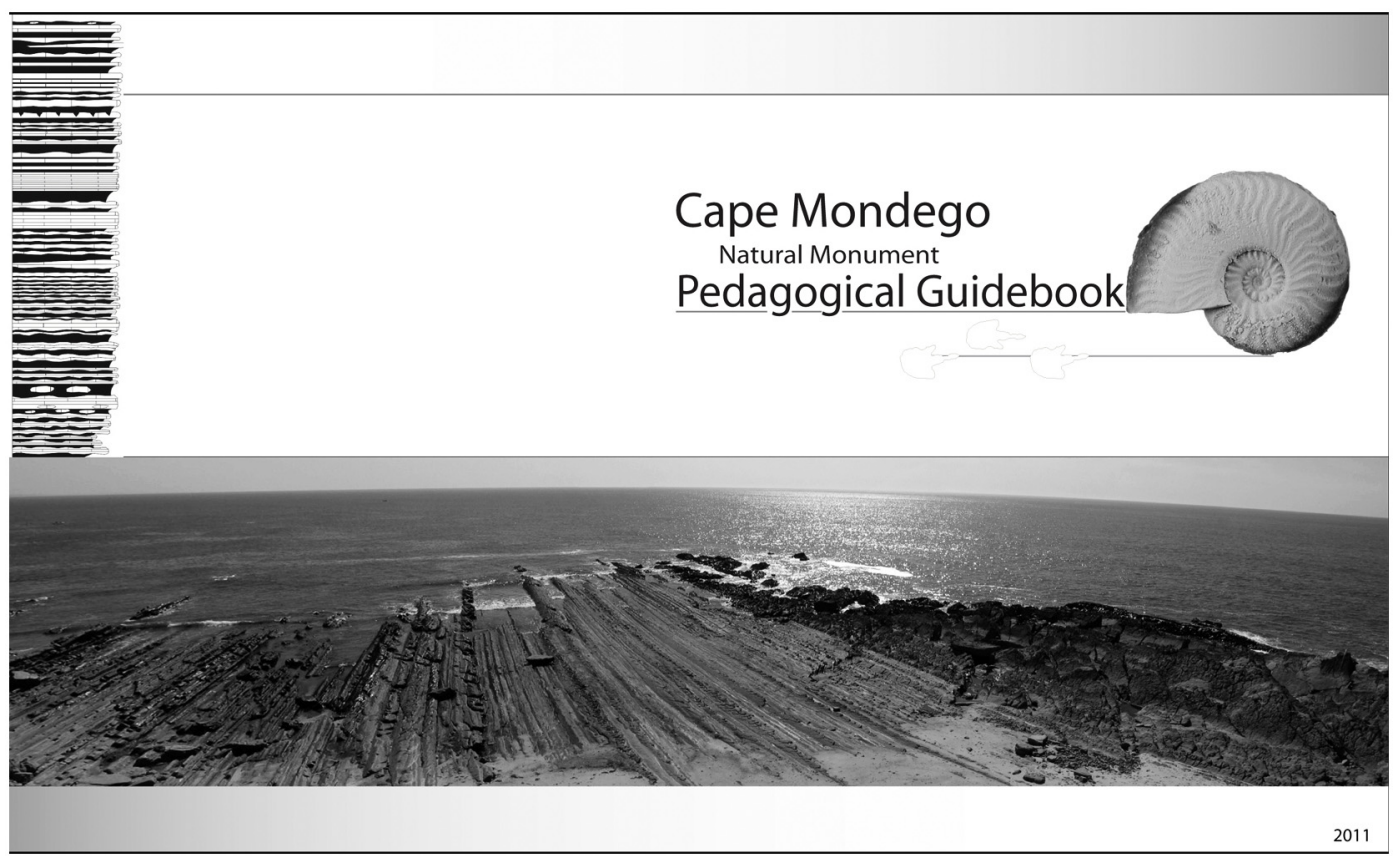

Fig. 3. Cape Mondego textbook front cover

\section{...a truly Jurassic Park from the Dinosaurs age...}

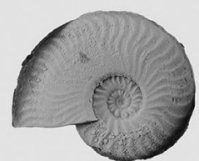

Cape Mondego Natural Monument

From the sea cliffs of Cape Mondego to Bandeira viewpoint on the top of the mountain, there are rocks that were formed 161 million years ago

The geological exceptionality of Cape Mondego led to its classification as a Natural Monument in 2007 and to the establishment of an international stratigraphic reference standard in 1996.

The geological heritage of Cape Mondego includes dinosaur footprints, macrofossils of ammonites, corals, plants, fish, and brachiopods and microfossils of foraminifers, calcareous nannoplakton, and radiolarians.
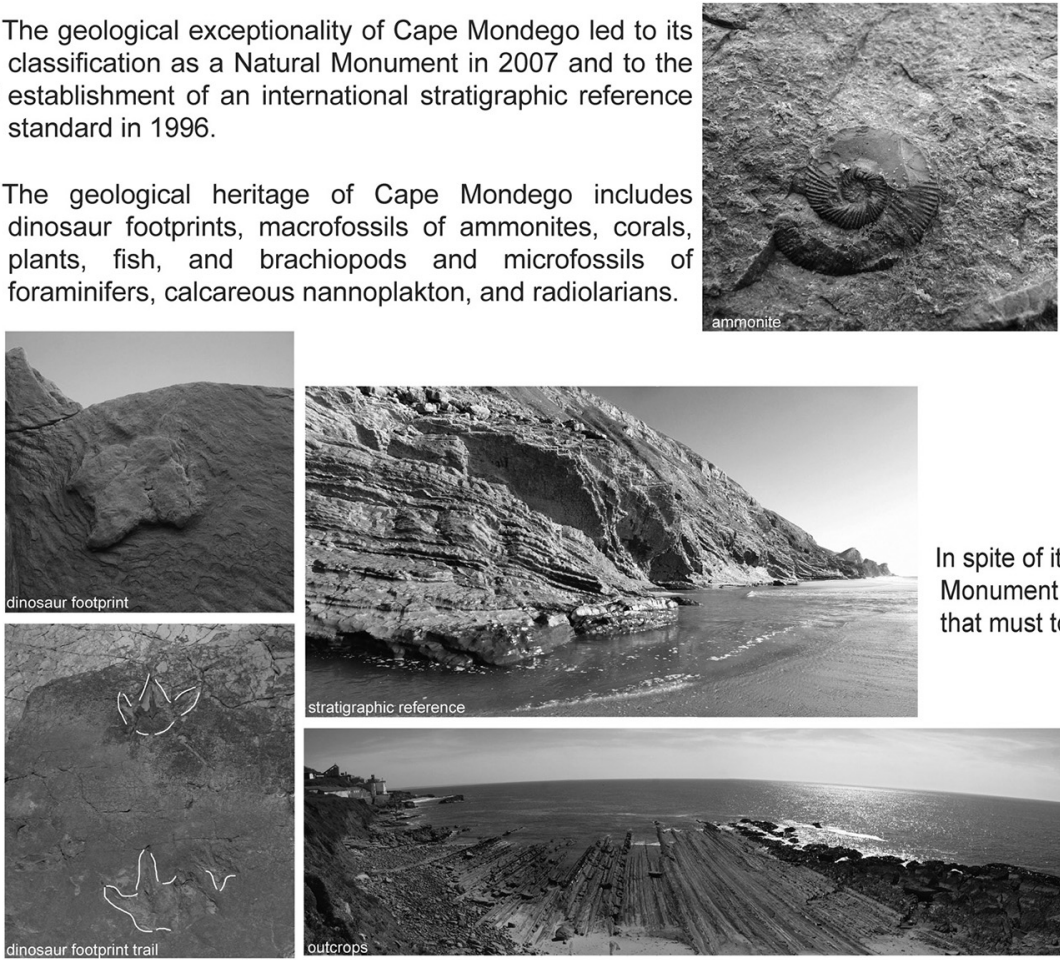

In spite of its relative small area, the Natural Monument exhibits a remarkable geodiversity that must to be well known and preserved.

Did you know.

The Cape Mondego is one of the best places in the world to understand the formation of the Atlantic Ocean!

The first Portuguese coal mining company was located in Cape Mondego

Fig. 4. Cape Mondego informative panel. 
The present study has some limitations: twelve geosites were considered, although only nine of them are located within the natural monument boundaries. Cape Mondego geological heritage is wider and holds more values than those, which were included in the assessed geosites list. The Cape Mondego scientific value has been expanding, as scientific communities are validating new scientific developments regarding the stratigraphic successions there recognized. Take the example of the GSSP establishment in 1996, which preceded the Bathonian ASSP establishment in 2008, more than a decade lag. Thus, the number of geosites defined in this work should not be seen as tight, but is likely to increase due to the dynamic character inherent to scientific knowledge production.

The geosite inventory is an important tool to define different protection levels and to support the implementation of conservation and management policies and strategies. It can be used to establish priorities for the application of protection measures and to support the definition of geoconservation strategies.

It is expected that the work now produced could contribute to the appreciation of the Cape Mondego geological importance, and that it increases public awareness about the importance of geoconservation policies for nature conservation and land-use management. The methodology applied to Cape Mondego geosites can be used as a support tool to assess geosites in other size areas and in other countries.

\section{Appendix A. Supplementary data}

Supplementary data associated with this article can be found, in the online version, at http://dx.doi.org/10.1016/j.pgeola.2013.04.005. These data include Google maps of the most important areas described in this article.

\section{References}

Braga, J.C. (Coord.), 2002. Propuesta de estratégia andaluza para la conservación de la geodiversidad [Andalucia strategy proposal for the conservation of geodiversity]. Junta de Andalucía, Consejería de Medio Ambiente, 105 pp. (in Spanish).

Brilha, J., 2002. Geoconservation and protected areas. Environmental Conservation 29 (3) $273-276$

Brilha, J., 2005. O Património Geológico e Geoconservação: a Conservação da Natureza na sua vertente Geológica. (The Geological Heritage and Geoconservation: the Nature Conservantion on its Geological feature).Palimage Editores 183 pp. (in Portuguese).

Brilha, J.B., Andrade, C., Azerêdo, A., Barriga, F., Cachão, M., Couto, H., Cunha, P.P., Crispim, J.A., Dantas, P., Duarte, L.V., Freitas, M., Granja, H.M., Henriques, M.H. Henriques, P., Lopes, L., Madeira, J., Matos, J.M.X., Noronha, F., Pais, J., Piçarra, J., Ramalho, M., Relvas, J., Ribeiro, A., Santos, A., Santos, V., Terrinha, P., 2005. Definition of the Portuguese frameworks with international relevance as an input for the European geological heritage characterisation. Episodes 28 (3) $177-186$.

Canales, M.L., Henriques, M.H., 2008. Foraminifera from the Aalenian and the Bajocian GSSP (Middle Jurassic) of Murtinheira section (Cabo Mondego, West Portugal): biostratigraphy and paleoenvironmental implications. Marine Micropaleontology 67 (1/2) 155-179.

Canales, M.L., Henriques, M.H., 2013. Foraminiferal assemblages from the Bajocian Global Stratotype Section and Point (Cape Mondego, Portugal). Journal of Foraminiferal Research 43 (2) 182-206.

Coratza, P., Bruschi, V.M., Piacentini, D., Saliba, D., Soldati, M., 2011. Recognition and assessment of geomorphosites in Malta at the Il-Majjistral nature and history Park. Geoheritage 3, 175-185.

Fassoulas, C., Mouriki, D., Dimitriou, P., Iliopoulos, G., 2011. Quantitative assessment of geotopes as an effective tool for geoheritage management. Geoheritage 3, 177-193.

Fernández-López, S., Pavia, G., Erba, E., Guiomar, M., Henriques, M.H., Lanza, R., Mangold, C., Olivero, D. Tiraboschi, D., 2009. The Global Boundary Stratotype Section and Point (GSSP) for base of the Bathonian Stage (Middle Jurassic), Ravin du Bès Section, SE France. Episodes 32 (4) 222-248.

Grandgirard, V., Szepesi, A., 1997. Geomorphology and management of natural heritage (the protection of the geotopes, a new task in geomorphology). Noosfera 3, 59-65.

Gray, M., 2004. Geodiversity. Valuing and Conserving Abiotic Nature. Wiley, Chichester, pp. 448.
Gray, M., 2008. Geodiversity: developing the paradigm. Proceedings of the Geologists' Association 119, 287-329.

Gray, M., 2011. Other nature: geodiversity and geosystem services. Environmental Conservation 38 (3) 271-274

Henriques, M.H., 1998a. O GSSP (Global Stratotype Section and Point) do Bajociano (Cabo Mondego, Portugal).(Bathonian GSSP (Cape Mondego, Portugal)). In: Tomás, J.O., Dias, R. (Eds.), Livro Guia das Excursões do V Congresso Nacional de Geologia, Excursão 1-O Mesozóico da Bacia Lusitânica. (in Portuguese), pp. 59-63.

Henriques, M.H., 1998b. O Jurássico do Cabo Mondego e a projecção internacional do património geológico português. (The Jurassic of Cape Mondego and international projection of the portuguese geological heritage).In: I Encontro Internacional sobre Paleobiologia dos Dinossáurios. (in Portuguese), pp. 98103.

Henriques, M.H., 2004. Jurassic heritage of Portugal: state of the art and open problems. Rivista Italiana di Paleontologia e Stratigrafia 10, 389-392.

Henriques, M.H., 2008. Cabo Mondego, Monumento Natural.(Cape Mondego Natural Monument). Geonovas 21, 3-4 (in Portuguese).

Henriques, M.H., Sadki, D., Mouterde, R., 1988. Graphoceratidés (Ammonitina) de la base du Bajocien portugais. In: Rocha, R.B., Soares, A.F. (Eds.), 2nd International Symposium on Jurassic Stratigraphy I. (in French), pp. 243-254.

Henriques, M.H., Gardin, S., Gomes, C.R., Soares, A.F., Rocha, R.B., Marques, J.F., Lapa, M.R., Montenegro, J.D. 1994. The Aalenian-Bajocian boundary at Cabo Mondego (Portugal). Miscellanea del Servizio Geologico Nazionale V, 63-77.

Henriques, M.H., Pena dos Reis, R., Brilha, J., Mota, T., 2011. Geoconservation as an emerging geoscience. Geoheritage 3, 117-128.

Henriques, M.H., Tomaz, C., Sá, A.A., 2012. The Arouca Geopark (Portugal) as an educational resource: a study case. Episodes 35 (4) 481-488.

Holtz, T.R., 1998. Theropod paleobiology, more than just bird origins. Gaia-Revista de Geociências 15, 1-3.

Kavčič, M., Peljhan, M., 2010. Geological heritage as an integral part of natural heritage conservation through its sustainable use in the Idrija region (Slovenia). Geoheritage 2, 137-154.

Lima, F., Brilha, J., Salamun, E., 2010. Inventorying geological heritage in large territories: a methodological proposal applied to Brazil. Geoheritage 2, 91-99.

Lockley, M.G., Meyer, C.A., Santos, V.F., 1998. Megalosauripus, and the problematic concept of Megalosaur footprints. Gaia-Revista de Geociências 15, 313317

Mouterde, R., Rocha, R., Ruget, C., 1978. Stratigraphie et faune du Lias et de la base du Dogger au Nord du Mondego, Quiaios et Brenha. (Stratigraphy and fauna at Lias and Dogger base, north of the Mondego, Quiaios and Brenha).In: Comunicações dos Serviços Geológicos de Portugal Tomo LXIII. (in French), pp. 83104.

Neto, K.S., Henriques, M.H. Antunes, R.L. 2011. Nanofósseis calcários da passagem Aaleniano-Bajociano do perfil do Cabo Mondego - Portugal (GSSP do Bajociano). Boletim de Geociências da Petrobras 19 (1/2) 235-250 (in Portuguese).

Newsome, D., Dowling, R.K., 2006. The scope and nature of geoturism. In: Dowling, R.K., Newsome, D. (Eds.), Geoturism. Elsevier, Amsterdam, pp. 3-25.

Panizza, M., Piacente, S., 2003. Geomorphological Assets Evaluation. Zeitschrift fur Geomorphologie 87 (Suppl. Bd.) 13-18.

Pavia, G., Enay, R., 1997. Definition of the Aalenian-Bajocian Stage boundary. Episodes 20 (1) 16-22.

Pellitero, R., González-Amuchastegui, M.J., Ruiz-Flaño, P., Serrano, E., 2011. Geodiversity and geomorphosite assessment applied to a natural protected area: the Ebro and Rudron Gorges Natural Park (Spain). Geoheritage 3, 163-174.

Pereira, P., Pereira, D., Alves, M., 2007. Geomorphosite assessment in Montesinho Natural Park (Portugal). Geographica Helvetica, Swiss Journal of Geography 3 , 159-168.

Reis, R.P., 2008. In: Pena, P.R., Pimentel, N. (Eds.), Síntese da evolução geodinâmica da Bacia Lusitânica durante o Mesozóico e o Cenozóico. (Summary of the geodynamic evolution of the Lusitanian Basin during the Mesozoic and Cenozoic).Roteiro do III Curso de Campo na Bacia Lusitânica, (in Portuguese), pp. 33-42.

Reis, R.P., Henriques, M.H., 2009. Approaching an integrated qualification and evaluation system for geological heritage. Geoheritage 1, 1-10.

Reynard, E., 2005. Geomorphosites et paysages. Géomorphologie: Relief, Processus, Environnement 3, 181-188.

Reynard, E., 2009. The assessment of geomorphosites. In: Reynard, E., Coratza, P., Regolini-Bissig, G. (Eds.), Geomorphosites. Verlag Dr. Friedrich Pfeil, Munchen, $240 \mathrm{pp}$

Rocha, J., 2010. O Monumento Natural do Cabo Mondego - proposta para uma estratégia de geoconservação e de um plano de ordenamento. (Cape Mondego Natural Monument-geoconservation strategy and a management plan proposals).In: Tese de Mestrado em Património Geológico e Geoconservação. Universidade do Minho (in Portuguese)

Rocha, R., Manuppella, G., Mouterde, R., Ruget, C., Zbyszewsky, G., 1981. Carta Geológica de Portugal na escala 1:50000. (Portuguese geologic map, scale 1:50000).Notícia explicativa da folha 19-C, Figueira da Foz, Serviços Geológicos de Portugal, Lisboa (in Portuguese).

Rocha, R., Henriques, M.H.P., Soares, A.F., Mouterde, R., Caloo, B., Ruget, C., Fernández-López, S., 1990. The Cabo Mondego section as a possible Bajocian boundary stratotype. Memorie Descrittive della Carta Geologica d'I XL, 49-60.

Serrano, E., González-Trueba, J.J., 2005. Assessment of geomorphosites in natural protected areas: the Picos de Europa National Park (Spain). Géomorphologie: Relief, Processus, Environnement 3, 197-208. 